\title{
プラズマ照射を利用するポリ乳酸二重錠剤からの テオフィリンの溶出制御
}

\section{葛谷昌之・伊藤英樹 - 野田菜穗子*1), 山川一郎 - 渡辺純男*2)}

Release control of theophylline from plasmairradiated double-compressed tablet composed of polylactic acid as a wall material

Oxygen plasma-irradiation (radio frequency discharges operating at $13.56 \mathrm{MHz}$ with less than 10 W) on the compressed tablet of one of the bioerodible polymers, polylactic acid(PLA), was found to cause only low efficiency in its degradation to such an extent as has been observed with polystyrene. Thus, controlled-release tablets have been obtained by oxygen plasma irradiation on the outermost layer of the double-compressed tablet which were fabricated from theophylline tablet as a core materials and a mixture of plasma-degradable polyoxymethylene (POM) and bioerodible PLA as a wall material. Dissolution test clearly indicated that the theophylline has been released from the tablet through the resulting micropore, while the release from untreated tablets was negligible.

It was also found that dissolution profiles are capable of being varied so as to cause release of theophylline at different rates, depending on the set of conditons chosen for tablet fabrication as well as plasma operational conditions.

Masayuki Kuzuya $\cdot$ Hideki Ito $\cdot$ Nahoko Noda ${ }^{* 11}$, Ichiro Yamakawa. Shumio Watanabe*2)

key words : plasma-processing, duoble-compressed tablet, theophylline, polylactic acid, controlled-release

前報において 0 次放出速度を目的・機能とした 医楽品の DDS 設計の一つとして, プラズマ分解 型高分子であるポリオキシメチレン(POM)およ びプラズマ架橋型高分子であるポリスチレン

*1) Laboratory of Pharmaceutical Physical Chemistry, Gifu Pharmaceutical University 岐阜薬科大学薬品物 理化学数室

*2) Tsukuba Research Laboratories, Eizai Co. Ltd. エー ザイ，筑波研究所
(PST)粉末が外層として配合されたテオフィリ ン含有二重錠剤を製造したのち，その外層表面に 酸素プラスママを照射すると, POM 部が分解飛散 するため, 多孔性外層を有する二重錠剤が得られ, 薬物に対する照射プラズマの直接被爆を回避し, かつ, プラズマ照射条件および二重錠剤成形条件 の選択によりテォフィリンの放出パターンを容易 にコントロール出来ることを報告した11.

本報告においては，プラズマ架橋型高分子の PST にかわって生分解性高分子の一つであるポ リ乳酸(PLA)と POM 粉末が外層に配合された テオフィリン含有二重錠剤を製造し，低出力領域 での酸素プラズマ照射条件および二重錠剤成形条 件のテオフィリン溶出性に及ぽす影響について検 討した.

その結果, 低出力のプラズマ照射においても, POM は高分解性を示すものの, PLA はPST と 同様にきわめて低分解性であることが示された。 したがって，本二重錠剤におけるテオフィリンの 溶出性も，その外層表面への酸素プラズマ照射条 件扔よび二重錠剂成形条件の選択により容易に制 御可能であることが示された。

\section{実験と実験方法}

\section{(1) 試料と材料}

(1) ポリ乳酸 (PLA)

Mw 10,000 の市販 PLA(和光純薬工業(株))を 乳錸中で粉砕し目的の篩を通して使用した。

(2) ポリオキシメチレン(POM)

前報と同様に文献記載の方法により合成し，目 的の篩を通して使用した。

(3) テォフィリン

市販品を $60^{\circ}$ で一日減圧乾燥し， 32 メッシュで 篩下して使用した。 
(4) 高分子直打錠剂

200 メッシュで篩下した POM，PST および PLA 粉末のそれぞれの $100 \mathrm{mg}$ を 5 分間の減圧 のあと, 打錠圧 $200 \mathrm{~kg} / \mathrm{cm}^{2}$ において 30 秒間圧縮 打錠し高分子錠剂(直径 $13 \mathrm{~mm}$ ) を得た。

(5) テオフィリン含有二重錠剤

芯物質としてテオフィリン $100 \mathrm{mg}$ を打錠圧 40 $\mathrm{kg} / \mathrm{cm}^{2}$ で 10 秒間圧縮打錠しテオフィリン錠剤 (直径 $10 \mathrm{~mm}$ ) とした. ついで外層高分子として POM および PLA の混合物を用いて 5 分間減圧 したあと, 打錠圧 $200 \mathrm{~kg} / \mathrm{cm}^{2}$ で 30 秒間圧縮打錠 しテオフィリン含有二重錠剤(直径 $13 \mathrm{~mm}$ )を得 た.

\section{（2）装置と操作方法}

(1) プラズマ照射装置およびプラズマ照射法は 前報に記載の方法 ${ }^{11} に$ 準じて行った。

(2) プラズマ照射による高分子分解速度の測定 POM, PST および PLA の直打錠凨に所定の 条件下酸素プラズマを照射し, 経時的に重量変化 を測定した. 重量測定には, 精度 $1 \mathrm{mg}$ の上血電 子天科 (メトラー社 PJ300 型)を用いて, プラズマ 照射錠剂の重量損失を測定した。

(3) 溶出試験

酸素プラズマを照射したテオフィリン含有二重 錠剤からのテオフィリンの溶出試験は日本薬局方 第 11 局に記載の回転バスケット法(富山産業(株) USP $(N F)$ 規格溶出試験器 TR-5S3, 溶出液 : 煮 沸により脱気した精製水, 溶出液温度 : $37 \pm 5^{\circ}$,バ スケット回転速度：100 rpm)により評価した。

テオフィリン溶出量は, 所定時間に試験器から 取り出した $3 \mathrm{ml}$ の溶出液を水で $20 \mathrm{ml}$ に希釈し, 紫外線吸光度法により $272 \mathrm{~nm}$ において定量し た.

\section{結果と考察}

（1）低出力下の酸素プラズ照射による POM, PST および PLA 直打錠剤の分解性

PLA (Mw10000)の融点(軟化点) は低く(50 〜 $55^{\circ}$ ), $10 \mathrm{~W}$ 以上のプラズマ照射出力においては プラズマ照射の熱的効果により溶融することが認 められたので, プラズマ照射は出力 $10 \mathrm{~W}$ 以下に 設定した.

図 1 は POM, PST および PLA 錠剤の酸素プ

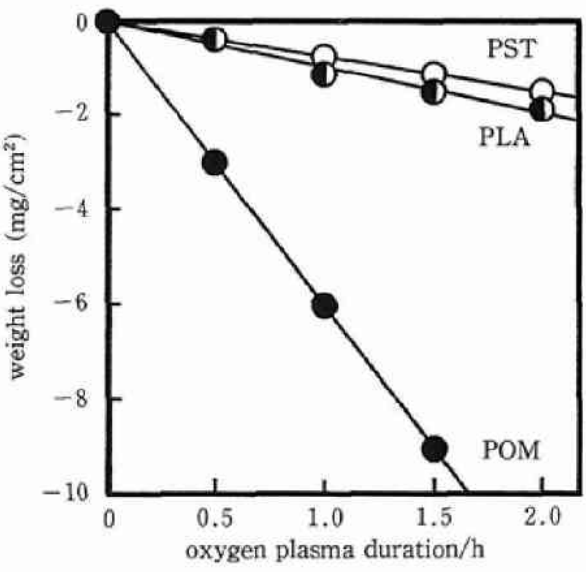

図 1 Effect of oxygen plasma-irradiation on polymer degradation

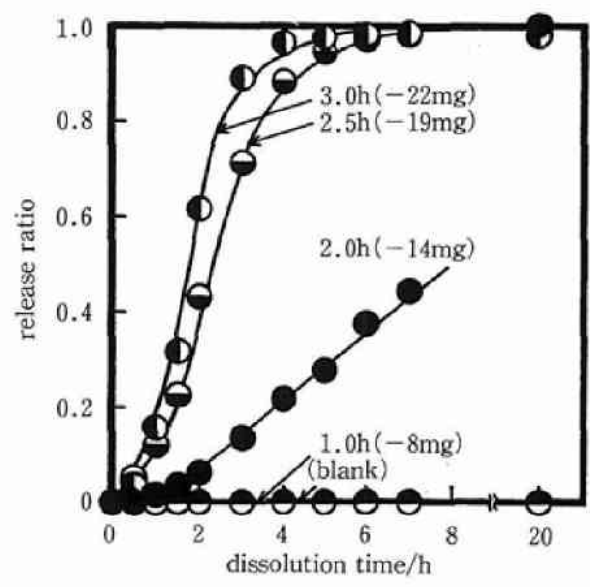

図 2 Effect of plasma-duration on dissolution property of theophylline

Outer layer : $80 \mathrm{mg}$ (POM : PLA =1:3), $\operatorname{POM}(60 \sim 80$ mesh $), \quad$ PLA $(100 \sim 140$ mesh).

Plasma conditions: $6 \mathrm{~W}, 0.5$ torr, $\mathrm{O}_{2} 50$ $\mathrm{ml} / \mathrm{min}$.

ラズマによる分解性を直打錠剂の重量損失により 検討した結果である。図1から明らかなようにプ ラズマ分解型高分子である POM は $6 \mathrm{~W}$ という 低出力においても出力 $50 \mathrm{~W}$ 時(前報1) と同様に 非常に大きな分解性を示している。一方, PLA は プラズマ架橋型高分子である PST と類似の低分 解性を示すことが明らかとなった.

このような PLA の低分解性は架橋反応が進行 しやすい PST と異なり，おそらく生成ラジカル 
がカルボニル基との共役によって安定化し, POM のような連鎖的解重合による低分子量物への分解 反応が進行しにくい結果と考えられる. 事実, PLA への長時間プラズマ照射によっても, PST において認められたような溶媒に不溶の架橋表面 層の形成はほとんど観察されなかった。また，プ ラズマ照射 PLA の IR, NMR スペクトルはプラ ズマ末照射 PLA と識別可能な差異は認められな かった.

（2）テオフィリン溶出性に対するプラズマ照 射条件の影響

図 2，3は，テオフィリンの溶出性に対するプ ラズマ照射時間とプラズマ照射出力の効果につい て示したものである.

図 2 から明らかなように, プラズマ末照射二重 錠剤からのテオフィリンの溶出は 20 時間後にお いてもまったく認められないが，プラズマ照射二 重錠剤からはテオフィリンの溶出が認められ，か つ, プラズマ照射時間の増加に従いテオフィリン 溶出性が上昇している，すなわち，本条件下での 1.0 時間のプラズマ照射においては細孔の形成は 不十分であり，また，テオフィリン溶出に対する プラズマ照射条件は 2.5 時間照射でほほ飽和に達 することなどがわかる。 また, いずれのテオフィ リンの溶出性もわずかなラグ時間を示すものの, ほほ 0 次放出速度に従う溶出パターンが達成され ている.

このような事実はプラズマ照射時間と POM の 重量損失量との関係から明らかなように, プラズ マ照射時間を增すことは POM の分解(図 2 中の カッコ内は重量損失 $\mathrm{mg}$ 数)に基づく細孔の形成 を高めた結果と考えられる.

さらに, 特筆すべきことは, 3.0 時間のプラズマ 照射においても，溶出時間 20 時間においてほぼ 100\%の溶出が達成されていることである.このこ とは, 低出力下では長時間プラズマ照射によって もテオフィリンの分解は完全に回避できることを 示している.

一方，プラズマ照射出力の効果についても図 3 から明らかなように, プラズマ照射出力を増すこ とによってテオフィリンの溶出速度は上昇してお り，いずれのプラズマ照射出力下においてもほぼ 0 次放出速度に従う良好なテオフィリンの溶出が

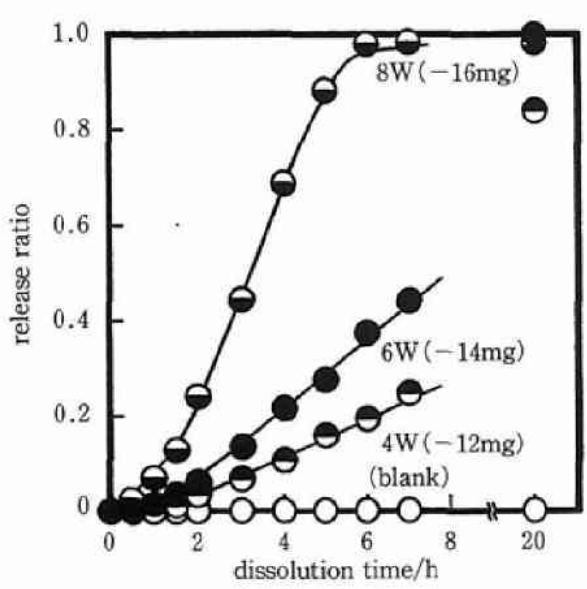

目 3 Effect of plasma supplied power (W) on dissolution property of theophylline

Outer layer : $80 \mathrm{mg}$ (POM : PLA $=1: 3$ ), $\operatorname{POM}(60 \sim 80 \mathrm{mesh}), \quad$ PLA $(100 \sim 140$ mesh).

Plasma conditions: $2 \mathrm{~h}, 0.5$ torr, $\mathrm{O}_{2} 50$ $\mathrm{ml} / \mathrm{min}$.

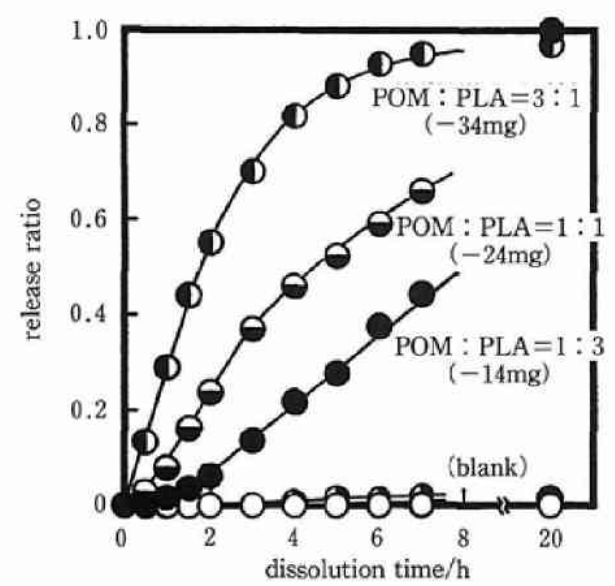

図 4 Effect of blending ratio between two polymers in the outer layer $(80 \mathrm{mg})$ on dissolution property of theophylline

Plasma conditions : $2 \mathrm{~h}, 6 \mathrm{~W}, 0.5$ torr, $\mathrm{O}_{2}$ $50 \mathrm{ml} / \mathrm{min}$.

示された.

このように本二重錠凨からのテオフィリンの溶 出速度はプラズマ照射条件の選択により制御可能 であることが示された。 


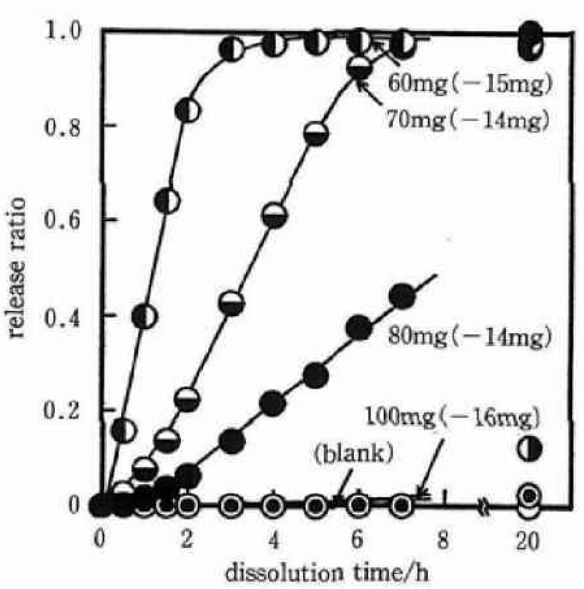

图 5 Effect of thickness (weight) of the outer layer (POM: PLA $=1: 3$ ) of double-compressed tablet on dissolution property of theophylline

Plasma conditions: $2 \mathrm{~h}, 6 \mathrm{~W}, 0.5$ torr, $\mathrm{O}_{2}$ $50 \mathrm{ml} / \mathrm{min}$.

（3）二重錠剂成形条件の選択によるテオフィ リン溶出制御

二重錠剤成形条件にはいくつかの要素が考えら れるが，ここでは，テオフィリンの溶出性に対す る外層配合高分子の配合比, 外層厚および高分子 粉末の粒子径の効果について検討した。 まず，外 層配合高分子の配合比が及ほすす効果について図 4 に示す.

プラズマ分解型高分子である POM の配合比が 増すとともに外層表面の POM 粒子数, すなわち プラズマ照射により生成する細孔数が増すため に, テオフィリンの溶出速度が上昇している。 ま た, いずれの条件においてもほほ 0 次放出速度に 従うテオフィリンの溶出性を示している.

一方, 図 5 は二重錠剤の外層重量, すなわち外 層厚の効果について示したものである. 外層厚の 増大とともにほほ 0 次放出速度に従うテオフィリ ンの溶出が抑制されるが，これは錠剤の重量損失 量がほぼ一定(14～16 mg)であることより，外層 重量の増大により細孔の形成が不完全となるため であり，本プラスマ照射条件において $100 \mathrm{mg} の$ 外層重量ではテオフィリンの溶出を可能にする細 孔の形成に至らなかったことがわかる. 最後に, 外層配合高分子の粒子径効果について図 6 に示 す.

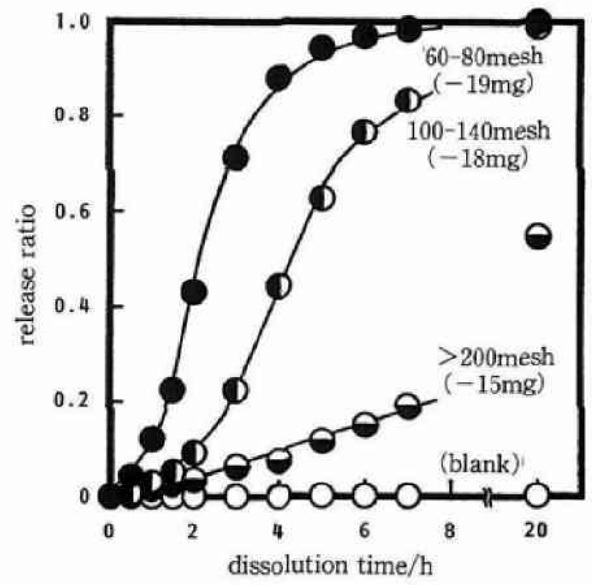

図 6 The effect of particle of POM in the outer layer on dissolution property of theophylline. PLA : $100 \sim 140$ mesh

Outer layer : $80 \mathrm{mg}$ (POM : PLA =1:3).

Plasma conditions : $2.5 \mathrm{~h}, 6 \mathrm{~W}, 0.5$ torr, $\mathrm{O}_{2}$ $50 \mathrm{ml} / \mathrm{min}$.

図 6 から明らかなように，プラズマ分解型高分 子である POM 粒子径すなわち, 細孔のサイズが 大きくなるに伴ってテォフィリンの溶出速度が上 昇すると同時に，その放出特性はリザーバー型徐 放錠に特有のシグモイドタイプのパターンを示す ようになる。このように外層配合高分子の粒子径 の選択によってもテオフィリン溶出速度の制御が 可能であることが示された.

\section{結 論}

PLA は低出力のプラス゚マ照射条件においてプ ラズマ架橋型高分子の PST と同様にきわめて低 分解性を示し, PLA とプラズマ分解型高分子であ る POM 粉末を外層として製造したテオフィリン 含有二重錠剤への酸素プラズマ照射は, POM 部 の分解飛散を効果的に引き起こし，多孔性外層を 有する二重錠椷を形成する，溶出試験結果はテオ フィリンがプラズマ照射により生じた細孔を通し て放出されることを示し，その溶出特性はプラズ マ照射条件および二重錠剂成形条件の選択により 容易に制御可能であり，0 次放出速度に従う二重 錠剤の構築も可能であることが示された.

本方法は, 薬物が照射プラズマに嚗されないこ とや完全ドライプロセスであるなどの利点のみな 
らず，PLA 外層を持つ本二重錠剤は PST 外層を 持つ二重錠剤(架橋反応が進行するため力学的強 度が高まる)にくらべ，力学的に脆弱であるもの の, 生分解性高分子の一つである PLA に本方法 の適用が可能であることは製㓲上きわめて意義ら゙ かく, プラズマ化学反応特性を利用した各種の目
的・用途汇適合するリザーバー型徐放錠の新しい DDS 構築法としての新たな展開が期待できる.

\section{文 献}

1）葛谷昌之, 野口章公, 伊藤英樹, 石川正直：プラスマ 照射医薬品添加物を利用する DDS の新展開. DDS 6 (2) : 119-125, 1991. 